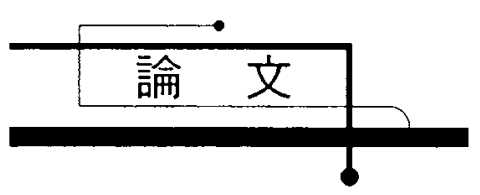

高速ウォータージェットの LIF-PTV 法による流速分布の測定*

\title{
Measurement of Velocity Profiles of High-Speed Water Jet Using LIF-PTV Method
}

\author{
阿部 宏 幸**吉田宏** 吉田憲 司***片岡勲*** \\ ABE Hiroyuki YOSHIDA Hiroshi YOSHIDA Kenji KATAOKA Isao
}

\begin{abstract}
The hydrodynamic structure of the high-speed water jet utilized in the jet grouting was experimentally investigated. The nozzle diameter of water jet ranged from 2 to $6 \mathrm{~mm}$, and the outlet pressure is up to $20 \mathrm{MPa}$, so the jet velocity reaches to several hundred meter per sec. The double-pulse Nd:YAG Laser and CCD camera with image intensifier were used to capture clear images of the water jet. From the captured images, velocity of water jet was measured using LIF technique combined with PTV at various locations from outlet of nozzle. The result showed the velocity of water jet remains its initial velocity at $400 D$ ( $D$ : nozzle diameters) from nozzle outlet. Radial velocity profile inside the jet showed flat velocity profiles for pressures and locations from outlet in the present experiment.
\end{abstract}

Keywords: Flow structure, High speed water jet, Water jet velocity, LIF-PTV method, Velocity profile

\section{1. 緒 言}

水をポンプで加圧しノズルから噴出させると、 極めて大きな破壊力を持ち、物体を切削できるこ とが古くから知られていた。近年では高速ウォー タージェットは産業分野で幅広く応用されてお り、布、皮革、金属等の切削加工や表面洗浄、外 科手術、土木建設工事(地盤の切削、コンクリー 卜構造物の解体等)等に利用されている[1-3]。そ れらのうち、土木建設工事の分野では、地盤改良 技術、杭打設工事、コンクリート切断技術が主要 な応用技術であり、ウォータージェットの特性が 有効に利用されており、他の方法では不可能であ った工事がウォータージェットを用いることに より容易かつ確実に行われるようになった。

この中でも特に重要であり、かつ最近実用化が 進んでいる技術にウォータージェットを用いた
地盤改良技術がある。高速ウォータージェットを 用いた地盤改良工法は地上から所定の深さまで 直径数十 $\mathrm{cm}$ 程度の比較的細い管を挿入し、管の 先端部からセメントなどの固化材を含んだ高圧 ジェットを噴射させ、周囲の土砂を削りながら混 合攪拌することにより、地中にセメント固化柱状 体を構築する地盤改良工法である。Fig.1 に地盤 改良に用いられているウォータージェットの噴 射装置を示す。

高速ウォータージェットは高速 (数百 $\mathrm{m} / \mathrm{s}$ )、高 圧（30〜200MPa）で気液二相流の複雑な構造を しているため、速度や、圧力等の流体力学的特性 を計測するのが難しく、高速自由噴流の速度や圧 力分布等の定式化もあまりなされておらず、構造 について十分な知見は得られていない。よってノ ズルの設計に関しては実験的なアプローチが多

* 2014.5.12 受付

*** 大阪大学大学院工学研究科機械工学専攻 干565-0867 大阪府吹田市山田丘 2-1

TEL: (06)6879-7256 FAX: (06) 6879-7256 E-mail: kataoka@mech.eng.osaka-u.ac.jp

** ケミカルグラウト株式会社技術本部技術開発部 
い。さらなる高性能ウォータージェットを開発す る為には、ノズルの改良が必要であり、そのため には高速自由噴流の基礎研究が必要である。これ までも、ウォータージェットの基礎的な特性の研 究は行われてきたが[4-7]、このような高速のウォ ータージェットの速度等の正確な測定は極めて 難しく行われてこなかった。近年、光学計器の発 達により高速の対象物を、高感度で撮影する事が 可能になった。それにあわせて、レーザー計測や PIV(Particle Image Velocimetry)、PTV(Particle Tracking Velocimetry)等の計測技術の発達により、 より高度な計測が可能になり、高速自由噴流に関 しても適応できるようになってきた。

本研究では高速ウォータージェットの構造解 明を目的とし、高速度カメラと、光を増幅し、電 子シャッターにより高速でシャッターを切れる イメージインテンシファイアーを使用した高速 ウォータージェットの画像撮影、及び流速測定法 を行った。ウォータージェットにローダミン B (Rhodamine B)を含んだ微小粒子を混入させ、この 粒子からレーザーにより誘起された蛍光を測定 することによりジェットの速度を計測する手法 PTV(Particle Tracking Velocimetry)を用いて、高速 ウォータージェットの速度分布を測定した。

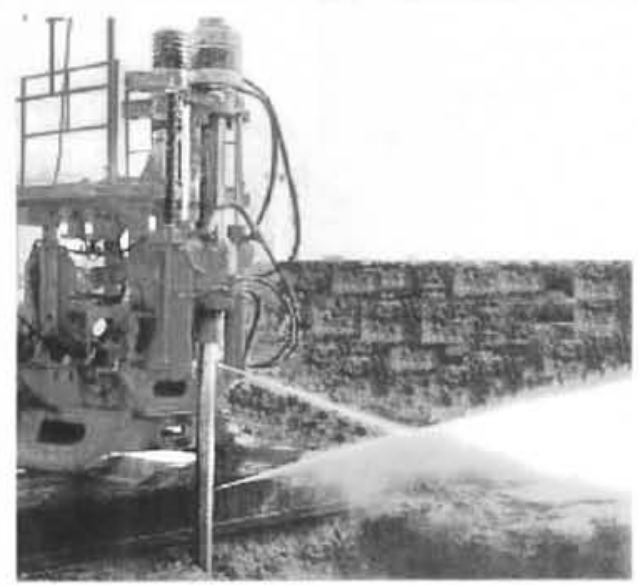

Fig. 1 Photograph of high-speed water jet utilized soil improvement.

\section{2. 実験装置}

実験装置の概略をFig.2 に示寸。実験装置はウォー夕 ージェット噴射装置とその測定装置からなる。測定装 置はNd:YAG ダブルパルスレーザーとイメージインテ
ンシファイアー付きCCDカメラとそれらを制御するパ ソコンからなる。

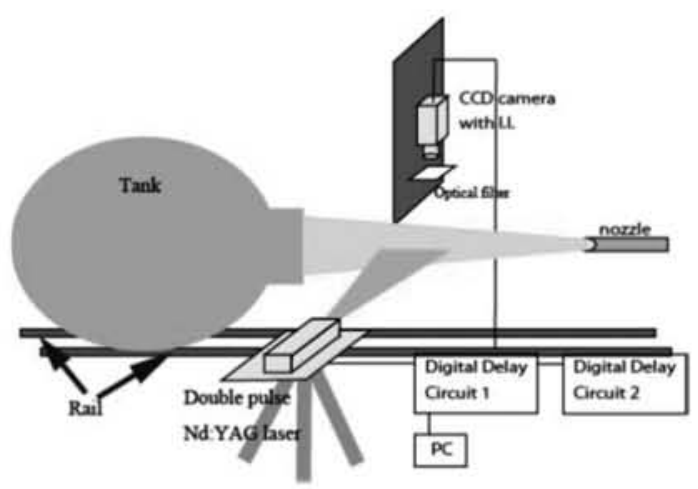

Fig. 2 Schematic drawing of experimental setup.

CCD カメラは浜松ホトニクス社製 C7972-11 で画 素は 1024×1024 ピクセルである。高速のジェットを攝 影する場合にはシャッタースピードを非常に早くする 必要があるため画像は暗くなる。そのため、光電子増 倍管によるイメージインテンシファイアーを取り付け てある。このイメージインテンシファイアーはゲート 回路を開く時間を電子的に制御できるため、実質的に $10 \mathrm{~ns}$ の露光時間での撮影が可能となる。また、このイ メージインテンシファイアーとCCDカメラをデジタル 遅延回路を用いて同期させる事により、最小で $1 \mu \mathrm{s}$ 間 隔で 2 枚の画像を撮影寸る事が出来る。これにより、 PTV 法による速度の測定が可能となる。

Nd:YAG ダブルパルスレーザーは New Wave 社製 PIV SOLO-120 であり、出力は $83 \mathrm{mj} /$ パルス、パルス幅 は $6 \mathrm{~ns}$ で532nm のグリーンのレーザーを出力する。レ ーザービームの径は6 $\mathrm{mm}$ であり、実験ではこれを円筒 レンズにより厚さ $0.1 \mathrm{~mm}$ 、幅 $150 \mathrm{~mm}$ のシート光にして、 ジェットの中心部を通過するように設定した。CCD カ メラを用いてこのシート状のレーザーに照射されてい る部分のジェットの画像を撮影した。また、ジェット の流動の様子を撮影するためハロゲンランプを用いた バックライト撮影も合わせて行った。

本実験では、動作流体の水に Rhodamine B を含 有した蛍光粒子(Lavision 社製の) 1002192、直径 $20 \mu \mathrm{m}-50 \mu \mathrm{m}$ 、密度 $\left.1190 \mathrm{~kg} / \mathrm{m}^{3}\right)$ を混入し、ノズルか ら噴射し Nd:YAG レーザーでジェットに対して 照射する。ジェット中の蛍光粒子は Nd:YAGレー ザー $(\lambda=532 \mathrm{~nm})$ の波長によって励起し、最大 $625 \mathrm{~nm}$ の波長の光を放出する。カメラの前に光学 フィルターを設置する。この光学フィルターは 
$565 \mathrm{~nm}$ 以下の光は $1 \%$ 以下しか透過しないので、 粒子以外のジェットの光をほとんど遮る。よって 粒子のみを撮影できる。これを連続して撮影し、 PTV(Particle Tracking Velocimetry)法を適用するこ とによって速度を計測できる。この方法 (LIF-PTV 法) の概略を Fig.3に示す。

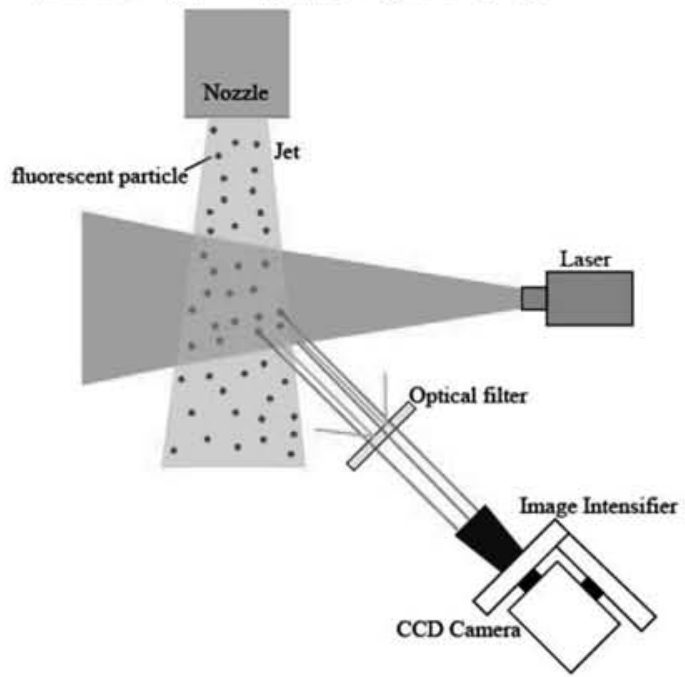

Fig. 3 Schematic drawing of Laser induced fluorescent method.

\section{3. 実験結果}

本実験ではウォータージェットのノズル径 $D$ として $2.5 \mathrm{~mm}$ のものを用いた。水道水をプラン ジャーポンプを用いて最大 $20 \mathrm{MPa}$ まで加圧して ノズルからウォータージェットを吐出させた。実 験ではノズル出口圧力を $1 \mathrm{MPa}$ から 20MPa まで 変化させた。プランジャーポンプの出口には十分 な体積をもつアキュムレータを設置してジェッ トが振動しないようにした。

ジェットの撮影はノズル出口からノズル径の $100 D(250 \mathrm{~mm}) 、 300 D(750 \mathrm{~mm}) 、 400 D(1000 \mathrm{~mm}) 、$ $600 \mathrm{D}(1500 \mathrm{~mm}) 、 800 \mathrm{D}(2000 \mathrm{~mm})$ の位置で行った。 撮影時間はイメージインテンシファイアーのゲ 一ト速度によって制御しこの実験では10ns とし た。Nd:YAG ダブルパルスレーザーのパルス幅は 6ns であるので、この CCD カメラの制御装置と同 期させる事により、画像の露光時間は $6 \mathrm{~ns}$ とする ことができる。これにより、数百 $\mathrm{m} / \mathrm{s}$ のジェット の鮮明な画像を撮影する事が可能となった。

\section{1 ジェットの挙動}

Fig.4 は通常のデジタルカメラで撮影したウォ
ータージェットの全体像である。この図は、ノズ ル出口圧力が $1 \mathrm{MPa}$ でノズル径は $2.85 \mathrm{~mm}$ のもの である (図にはスケールを入れてあるが斜め方向 から撮影しているので参考值である)。このよう に地盤改良用の高速ウォータージェットはノズ ル出口直後から、多くの液滴を伴った流れとなっ ており、流れ方向にジェットの幅は大きく広がっ ている。通常の露光時間ではジェットの内部の流 動の様子はほとんどわからない。

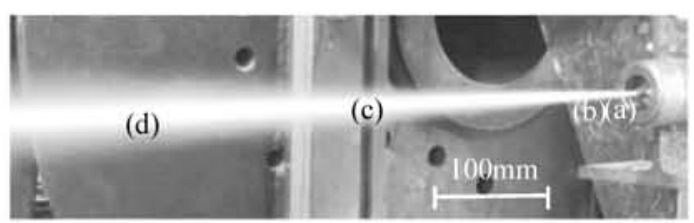

Fig. 4 Direct photograph of high-speed water jet captured with usual digital camera.

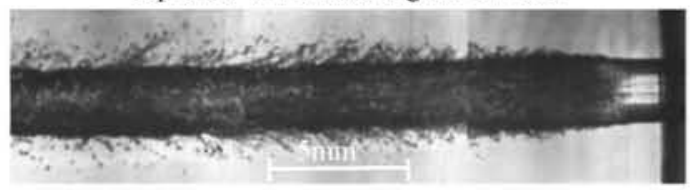

(a) $0 \mathrm{~mm}-23 \mathrm{~mm}$

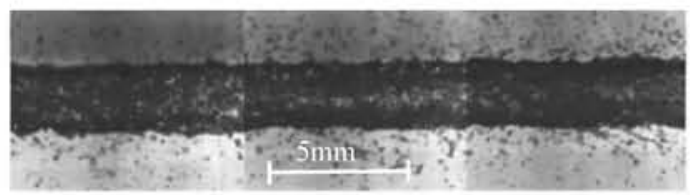

(b) $21 \mathrm{~mm}-44 \mathrm{~mm}$

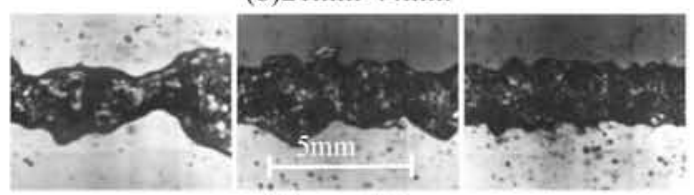

(c) $75 \mathrm{~mm}-300 \mathrm{~mm}$

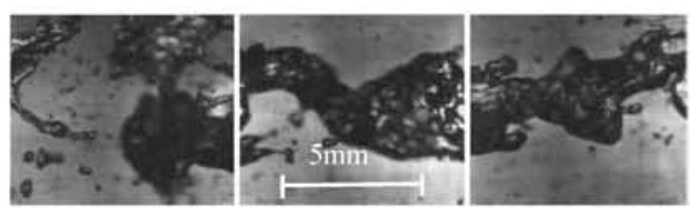

(d) $400 \mathrm{~mm}-600 \mathrm{~mm}$

Fig. 5 Typical jet profiles captured by backlight method.

Fig.5は同じ条件のウォータージェットを10ns の 露光時間で八ロゲンランプを用いてバックライ 卜撮影した画像である。それぞれの図の下の数値 
はノズル出口からの距離である。また、Fig.4に こららの画像を撮影した概略の位置を示してあ る。この図からわかるように、ウォータージェッ 卜はノズル出口直後では連続流となっているが、 ジェット界面に擾乱波が発生して大きく成長し、 波の先端からは液滴が発生している。Fig.4にお いて観察されているのはこうして発生した液滴 である。ノズル出口から $50 \mathrm{~mm}$ 程度まではジェッ 卜はほぼ左右対称で直線的であるが、その後ジェ ットの界面は大きく変形し非対称となり分裂し、 大きな液塊が発生している。ジェットの速度は大 きく変動し乱れた流れとなっている事がわかる。

\subsection{LIF-PTV 法による速度の測定結果}

Fig.6 に LIF-PTV 法による速度の測定に用いた 2 枚の連続した画像の一例を示す。2 枚の画像を 撮影するため、デジタル遅延回路として Stanford Research System 社製 DG535 を用いた。画像の遅 延時間は $4 \mu \mathrm{s}$ であり、その精度は $1.5 \mathrm{~ns}$ である。 Fig.6 の右側の画像は左側の画像の撮影後 $4 \mu \mathrm{s}$ 後 に撮影したものである。図で流れ方向は下向きで ある。対応するローダミン粒子が、下向きに移動 している事がわかる。これらの粒子の移動距離か ら速度を求めることが可能となり、この速度をも ってその粒子の位置での瞬時のジェット速度と する（ローダミン粒子は十分小さく流れに追従し ていると仮定する)。

画像の撮影サイズは $17.5 \mathrm{~mm} \times 17.5 \mathrm{~mm}$ であり、 ピクセル数は 1024 ピクセル $\times 1024$ ピクセルであ り空間分解能は $17.1 \mu \mathrm{m} /$ ピクセルである。この画 像の空間分解能と画像の遅延時間から、ここでの LIF-PTV 法による速度の測定精度は $3.89 \mathrm{~m} / \mathrm{s}$ と見 積もられる。

このような連続した画像を各圧力、ノズル出口 からの各位置について 200 組撮ることによって ジェットの半径方向の各位置における瞬時の速 度の分布を求めた。なお画像から速度を求めるに あたってはアートテクノロジー株式会社の PTV ソフトウェア ZVECTOR を用いた。ここでの LIF-PTV 法による測定が可能であるためには、粒 子群が同一平面内に存在することが必要である。 Fig.6に示すように撮影した多数の $4 \mu \mathrm{s}$ 遅延した 画像において、粒子が新たに現れたり、消えたり するものはほとんじ観察されなかった。またここ での画像撮影に遅延時間は $4 \mu \mathrm{s}$ と短く、レーザー シートの厚さが $0.1 \mathrm{~mm}$ であることを考えると、
蛍光粒子がレーザーシートを通過するには $25 \mathrm{~m} / \mathrm{s}$ 程度の大きな半径方向の速度を持つ必要がある。 しかしながら、測定された速度は流れ方向の成分 がほとんどであり、半径方向の速度成分は極めて 小さかったこと、ならびに Fig.4に見られる様な ジェットの広がりから半径方向速度は $25 \mathrm{~m} / \mathrm{s} よ り$ 十分小さいと考えられることから、粒子群は同一 平面内に存在しているとの仮定は妥当なもので あると考えられる。

Fig.7から Fig.10は圧力 1MPa、5MPa、10MPa、 20MPa におけるノズル出口からの距離 $100 D$ 、 $200 D 、 300 D 、 400 D 、 600 D 、 800 D$ の各位置 でのジェットの半径方向の速度分布の測定結果 を示す。ここで $r$ はジェット中心からの位置であ り、Rはノズルの半径である $(D / 2)$ 。またこれらの 図の $100 D$ の位置の図にはノズル出口圧力 $P$ を用 いて次式のベルヌーイの式から求めた流速 $u$ を 示している。

$$
u=\sqrt{\frac{2 P}{\rho}}
$$

ここで $\rho$ は水の密度である。

これらの図からわかるように、半径方向の各位 置でのジェットの速度はおおむね式(1)による速 度に近い值となっている。また速度は大きく変動 していることがわかる。この速度の変動は、先に 述べた LIF-PTV 法による速度の測定誤差 $(3.89 \mathrm{~m} / \mathrm{s})$ やジェットによるレーザーシートや粒子からの 蛍光の屈折等の影響が含まれていると考えられ が、その変動の值は大きく (10m/s 程度)、Fig.5 に示したようにジェットの界面が大きく非対称 に歪み、波が発生し液滴が飛散することによるも のと考えられる。この変動は、乱流等のジェット の流体力学的構造に強く関係していると考えら れる。しかしながら本実験においてはその変動の 分散・ゆらぎ等の統計量を求めるには十分なデー 夕数がなく、分散・ゆらぎと距離 $D 、 r$ との関係 を定量的に議論するには至らなかった。Fig.7か ら Fig.10によりわかるように速度の変動は、圧 力が大きくなるに従い、またノズルからの距離が 大きくなるに従い大きくなっている。

また、Fig.7 から Fig.10 でノズル出口からの距 離が大きくなるに従い速度の計測点が半径方向 に広がっているのは、ジェットの幅が流れ方向に 広がっていることによる。圧力が高く、ノズルか 
らの距離が大きいところでは、速度の測定結果が 得られていない。これは、この領域ではジェット からの液滴（ミスト）の発生が非常に多くなり、 カメラが液滴で濡れてしまうため撮影ができな くなったことによる。また、測定されている条件 でも、大量のミストによりローダミン粒子からの レーザー蛍光が遮られて、十分な数の粒子データ が得られない場合があった。また高圧の $600 D$ 、 800D ではジェットの広がりが大きく、CCDカメ ラで撮影する範囲の外にまでジェットが広がっ ているため、ジェットのすべての領域の速度を測 定することが出来なかった。

Fig.7 から Fig.10 における半径方向における 各位置の瞬時の速度データを平均して、平均速度 の半径方向分布を求めた結果を Fig.11 から Fig.16 に示す。平均にあたっては半径方向距離 $r$ が $0.4 \mathrm{~mm}$ 間隔のデータを平均した（但、 $1 \mathrm{MPa} の$ $100 D 、 200 D$ について $0.2 \mathrm{~mm}$ 間隔で平均)。

Fig.11 はノズル出口近くの $100 D$ における平均 速度分布である。ノズル出口圧力が $1 \mathrm{MPa}$ の場合 にはジェットの速度分布はほぼ一様でありジェ ットの広がりは $3 R(1.5 D)$ 程度でほとんど広が っておらず、収束した連続流に近いジェットとな っている。ノズル出口圧力が 5MPa になるとジェ ットは $6 R$ 程度に広がる。中心部の速度は一様で あるが、気液界面で速度が大幅に減少している。 これはジェット速度が大きいため、気液界面で大 きな剪断力が働くことによると考えられる。ノズ ル出口圧力が $10 \mathrm{MPa}$ になるとジェット幅は更に 広がる。この場合もジェット中心部では速度分布 は一様であるが、周辺部で速度は 5MPa の場合に 比べてもさらに大きく減少している。

同様な傾向はFig.12の 200Dの場合にも見られ る。Fig.12で 20MPa のジェットの広がりが小さ くなっているように見えるが、これは 20MPa で は非常にミストの発生量が多く、周辺部でのロー ダミン粒子の画像がほとんどとれなかったこと
によるもので実際のジェット幅は大きくなって いる。

Fig.13 は 300D の場合の速度分布であるが、こ の場合には $1 \mathrm{MPa}$ の場合でもジェットの広がりは 大きく $8 R$ 程度にまでなっている。 $5 \mathrm{MPa} 、 10 \mathrm{MPa}$ では更にジェット幅が広がり $10 \mathrm{MPa}$ では速度分 布は中心部でも一様ではなく、山形の分布になっ ている。

Fig.14 $400 D$ の場合の速度分布であるが、 $1 \mathrm{MPa}$ でもジェットは $10 R$ 程度まで広がり、圧力 によるジェットの広がりの影響はあまり顕著で はなくなる。また、圧力が高くなるに従って、ジ エット周辺の速度が小さくなっている。この図で は圧力が大きい所でジェット幅が小さくなって いるように見えるが、これはジェット周辺部での ミストの影響により、ローダミン粒子の信号が少 なくなり、正確なデータが得られなくなったため であって実際には高圧の方がジェット幅は大き くなっている。

Fig.15 は 600D の場合の速度分布である。この

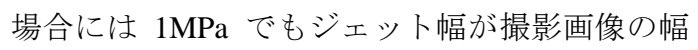
(14R) に達してしまっている。実際には、圧力 の高い領域では、ジェットはこれ以上に広がって いるが、撮影画像の制約から、これより外の速度 は計測されていない。圧力が高くなるほど、速度 のばらつきが大きく (サンプルデータ数が小さく なっている)、周辺部での速度の減少が顕著にな っている。

Fig.16 は 800D の場合の速度分布である。ミス 卜の発生が激しく撮影は $5 \mathrm{MPa}$ までしか行えなか った。まだ、ミストの量が非常に大きく、5MPa の場合でも周辺のミストによってローダミン粒 子の信号が阻害されデータが得られなくなって いる。しかしながら、この領域では $1 \mathrm{MPa}$ でも周 辺の速度の低下が見られ、5MPaになると、速度 分布は非対称となり、周辺で速度が大幅に減少し ている。 


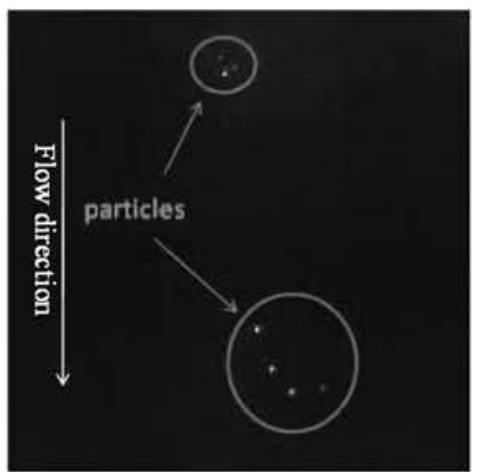

First photograph

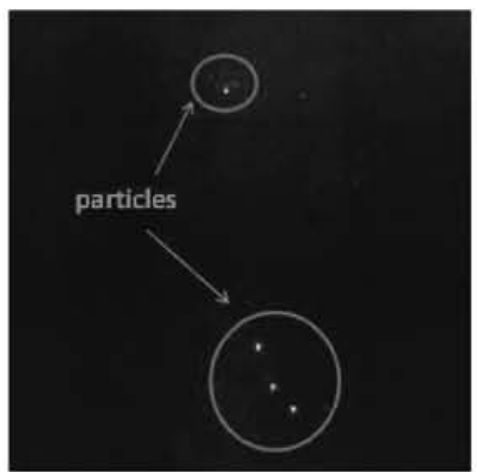

Second photograph

Fig. 6 An example of serial photographs captured by LIF for PTV.

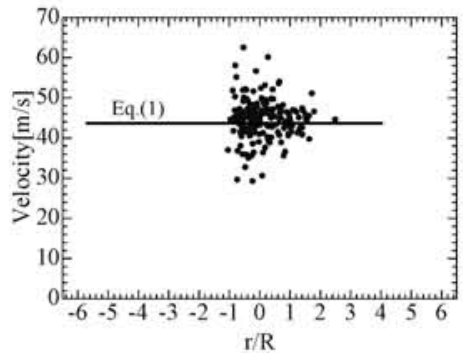

(a) $100 \mathrm{D}$

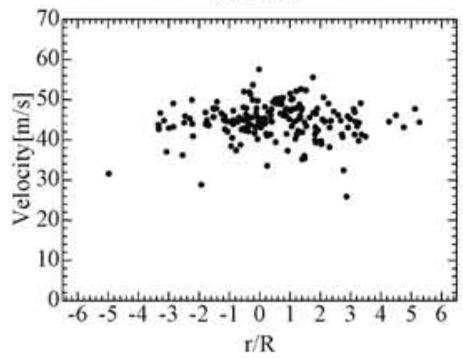

(c) 3000

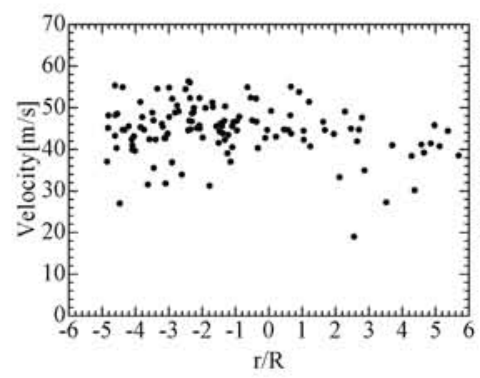

(e) $600 \mathrm{D}$

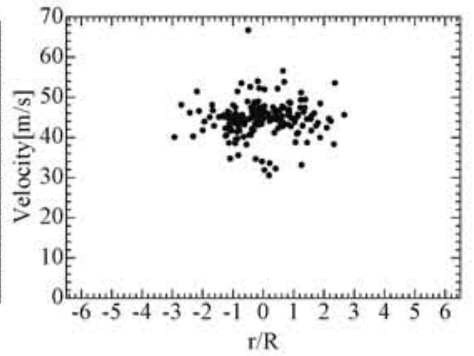

(b)200D

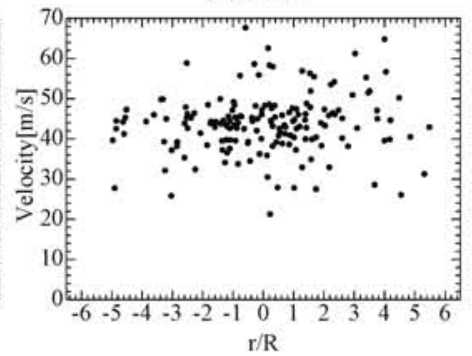

(d) $400 \mathrm{D}$

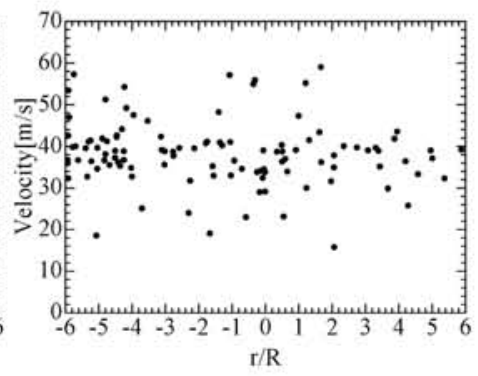

(f) $800 \mathrm{D}$

Fig. 7 All measured velocity data for the case of $1 \mathrm{MPa}$. 


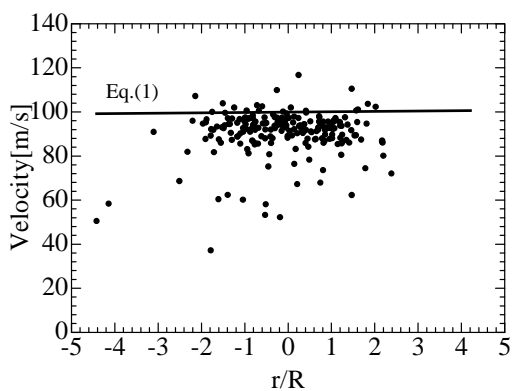

(a) $100 \mathrm{D}$

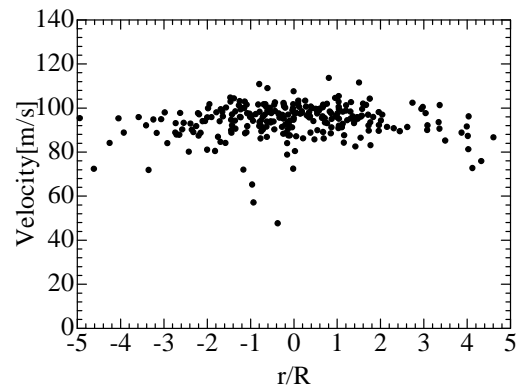

(c) $300 \mathrm{D}$

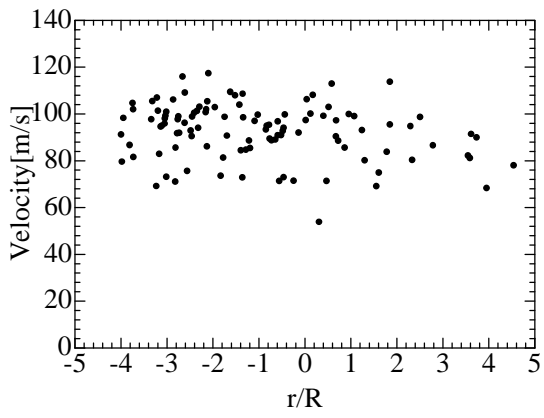

(e)600D

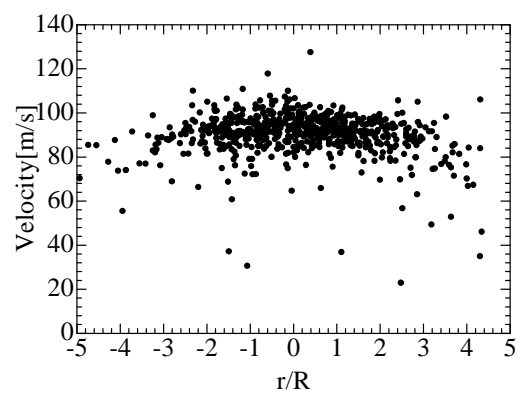

(b)200D

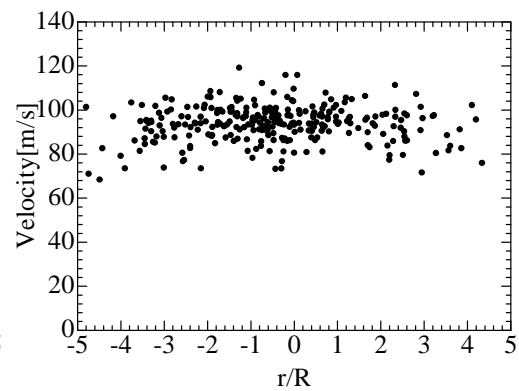

(d) $400 \mathrm{D}$

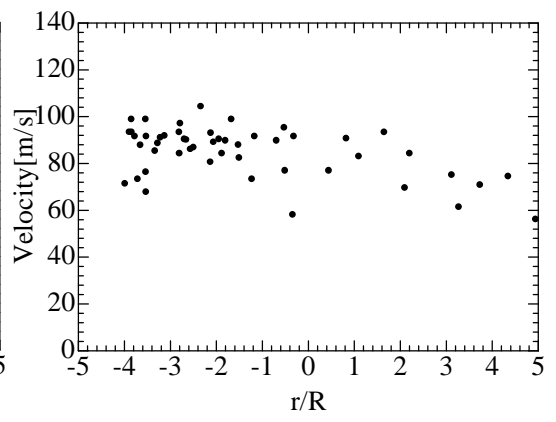

(f) $800 \mathrm{D}$

Fig. 8 All measured velocity data for the case of 5MPa. 


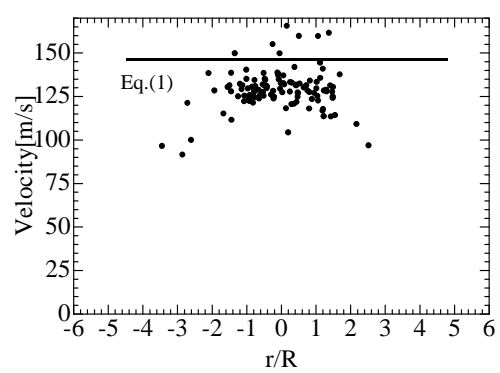

(a)100D

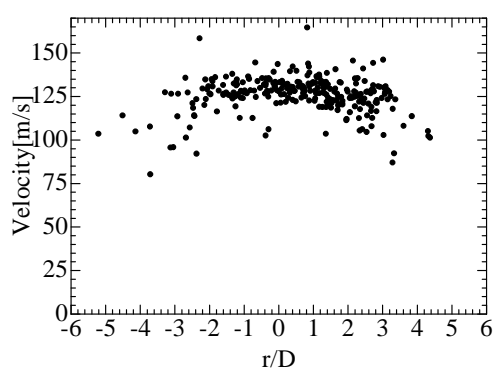

(b)200D

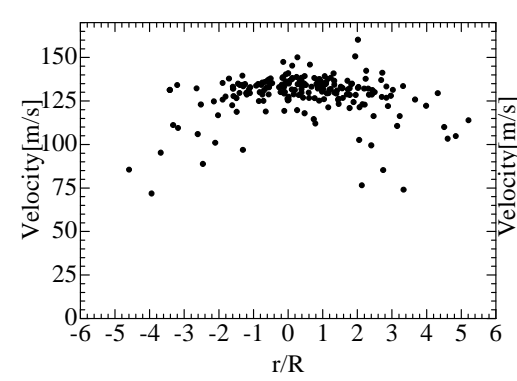

(c)300D

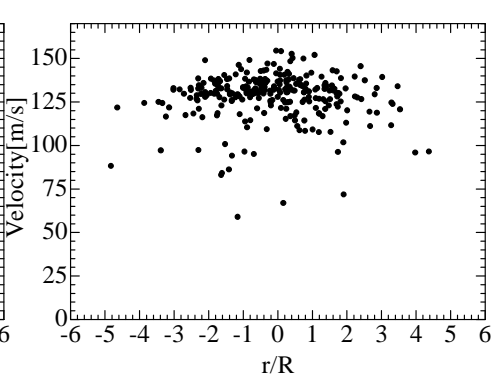

(d)400D

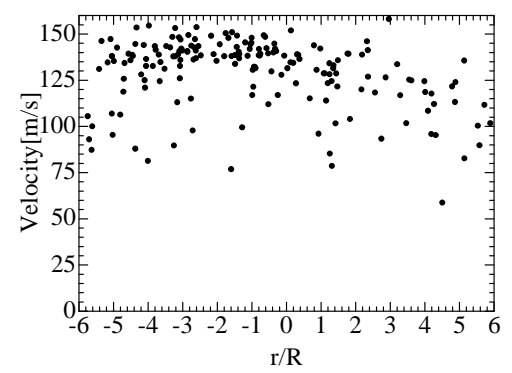

(e)600D

Fig. 9 All measured velocity data for the case of 10MPa.

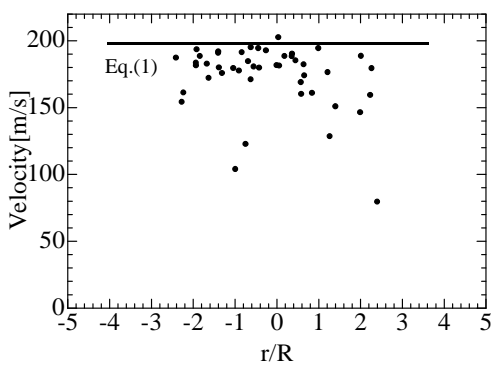

(a)100D

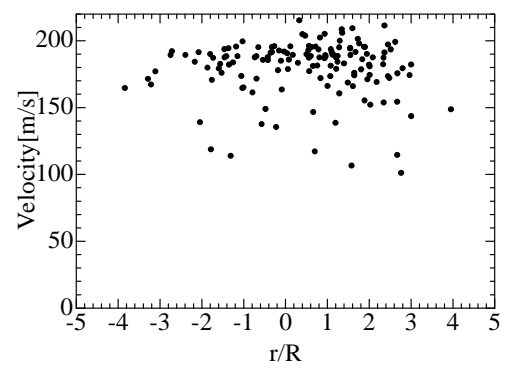

(b) $400 D$

Fig. 10 All measured velocity data for the case of 20MPa. 


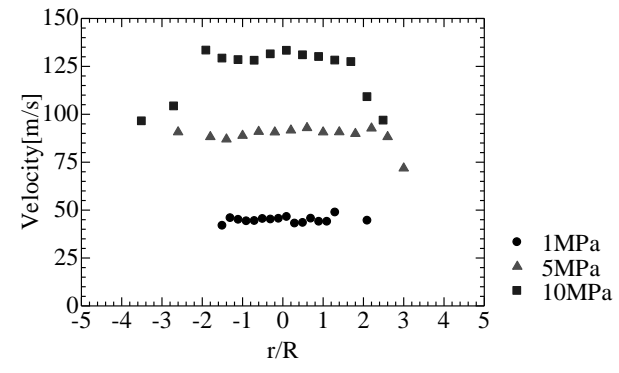

Fig. 11 Averaged velocity profiles at the position of $100 D$.

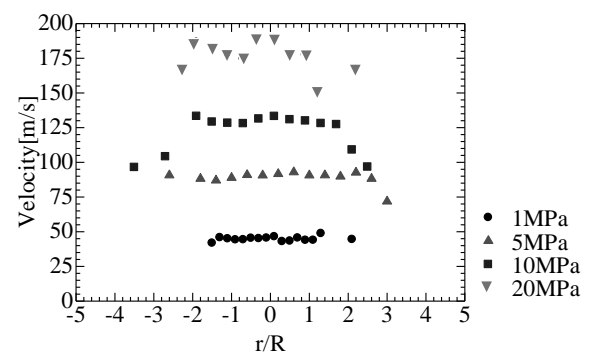

Fig. 12 Averaged velocity profiles at the position of $200 D$.

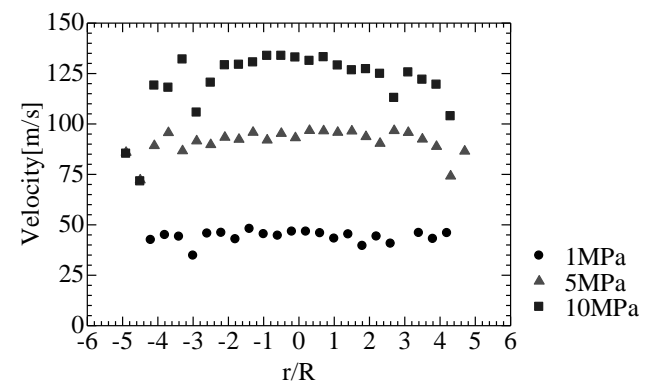

Fig. 13 Averaged velocity profiles at the position of $300 D$.

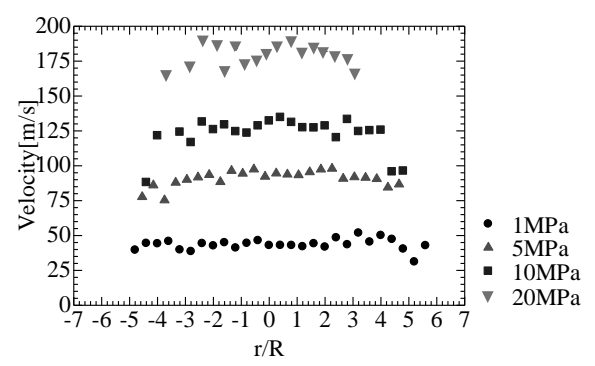

Fig. 14 Averaged velocity profiles at the position of $400 D$.

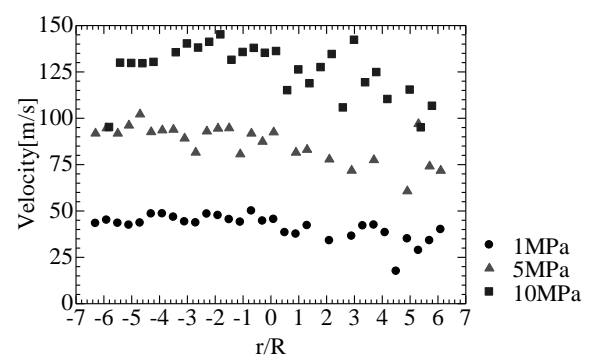

Fig. 15 Averaged velocity profiles at the position of 600D.

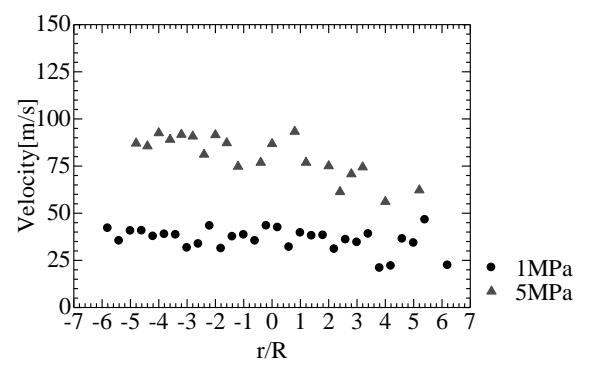

Fig. 16 Averaged velocity profiles at the position of $800 D$.

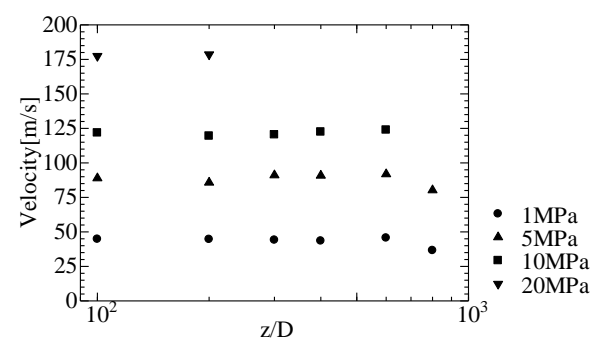

Fig. 17 Velocity profiles in axial direction.

Fig.17 は Fig.11 から Fig.16 の半径方向速度分 布を平均して断面平均速度を求め、そのノズル出 口からの影響を見たものである。この図からわか るように平均速度は各圧力とも $600 D$ まではあま り減衰していないことがわかる。また、Fig.7 か ら Fig.10 で示した様に、平均速度の值は、ノズ ル出口圧力からベルヌーイの定理を用いて求め た速度に近い值を示しており、測定結果は妥当な ものであると考えられる。しかしながら、Fig.7 から Fig.16の結果からわかるように、ノズル出 口からの距離が $400 D$ あたりから、速度のばらつ きが非常に大きくなると共に、ジェット周辺部で 
も速度の減少が著しくなっている。従って、速度 が一様で、ジェットの切削能力が維持されるのは おおむねノズル出口から $300 D$ から $400 D$ までと 考えられる。これは従来のジェット衝撃圧力の測 定結果とも[7]整合性を持ったものとなっている。

\section{3. 結 言}

地盤改良に用いられる高速ウォータージェッ 卜の流動構造を実験的に解明するため、Nd:YAG レーザーとイメージインテンシファイアー付き CCD カメラを用い、ローダミン B を含有した蛍 光粒子をトレーサとして、LIF-PTV 法により、速 度分布を測定した結果について報告した。ジェッ 卜の半径方向各位置における瞬時の速度は大き く変動しており、その変動幅はノズル出口からの 距離が大きくなるほど、またノズル出口圧力が大 きくなるほど大きくなることが明らかとなった。 ジェットの半径方向速度分布はノズル出口から $100 D$ の位置ではほぼ一様な分布であるが、ノズ ルからの距離が増加するに従い、ジェット周辺部 で速度が低下し、特に圧力が高い領域では山形の 分布、非対称な分布になっていくことが示された。 断面平均速度はノズル出口からの距離が $600 D$ 程 度まではあまり減衰しなかった。しかし速度分布 や、速度変動を考慮するとジェットの切削能力が 維持されるのは $300 D$ から $400 D$ 程度までと考え られる。

ここでの実験はノズル出口径が $2.5 \mathrm{~mm}$ の場合 について行った。実際の地盤改良に用いられるノ ズル出口径は $2 \mathrm{~mm}$ から $6 \mathrm{~mm}$ である。経験的には ノズル出口径がこの範囲で変化しても、ジェット の構造はほぼ同様であることが知られており、ジ エットの切削距離もノズル径にほぼ比例してい ることが知られている[7]。従ってここで得られた 流動構造は近似的に他のノズル径に対しても適 用出来ると考えられる。

また、本研究においてジェットの切削能力が維 持されるのは $400 D$ 程度となる結果が得られた。 地盤改良に際しては Fig.1 に示すように噴射管か ら斜めあるいは垂直にジェットを噴射し回転さ せて円柱状に掘削しコンクリートを流し込む。本 研究で用いた $2.5 \mathrm{~mm}$ の出口ノズル径の場合には $400 D$ の切削距離は約 $1 \mathrm{~m}$ であるので、半径 $1 \mathrm{~m}$ (直 径 $2 \mathrm{~m}$ ) の改良体（円柱状のコンクリート）が作 成できる。現在用いられている地盤改良の改良体
の直径は $2 \mathrm{~m}$ から $5 \mathrm{~m}$ 程度であるので、ここでの 結果は実際の地盤改良工事の実績とも整合性を 持ったものとなっている。

ここでの研究結果はより高圧、大流量、大口径 のノズルを開発する際や複数のジェットを組み 合わせてより高性能な切削装置を開発する場合 に設計の基礎的な知見として役立てることがで きると考えられる。

\section{Nomenclature}

$D \quad$ : nozzle diameter [m]

$P \quad$ : pressure [Pa]

$R \quad$ : nozzle radius [m]

$r \quad$ : radial position [m]

$u \quad$ : velocity $\quad[\mathrm{m} / \mathrm{s}]$

$\rho \quad$ : density $\quad\left[\mathrm{kg} / \mathrm{m}^{3}\right]$

\section{参考文献}

[1] The Water Jet Technology Society of Japan, Water Jet Technology Handbook, Maruzen, Tokyo (1993).

[2] Kiyohashi, H., Application of Water Jet Technology and Recent Developments (in Japanese), J. of the Japan Society of Mechanical Engineers, Vol.90, (829), 1487-1494 (1987).

[3] Yoshida, H., Current Status of the Application of Water Jet Technology in the Field of Industries, J. of Jet Flow Engineering, Vol.19, (2), 12-26 (2002).

[4] Phinney, R.E., The Breakup of Turbulent Liquid Jet in Gaseous Atmosphere, J. of Fluid Mechanics, Vol.60, 689-701 (1973).

[5] Kobayashi, R., Arai, T. and Yamada H., Structure of a Water Jet and Damage Process of Metals in Jet Cutting Technology, Transactions of the Japan Society of Mechanical Engineers, Series B, Vol.53, (489), 1539-1542 (1987).

[6] Yanaida, K. and Ohashi,A., Flow Characteristics of Water Jets in Air, Proceedings of 4th International Symposium of Jet Cutting Technology, Paper A3, BHRA (1978).

[7] Yahiro,Y. and Yoshida, H., On the Characteristics of High Speed Water Jet in the Liquid and its Utilization of Induction Grouting Method, Second Int. Symp. on Jet Cutting Technol. G4, Cambridge (1974). 